\title{
Potential Anti-Influenza Virus Agents Based on Coffee Ingredients and Natural Flavonols
}

\author{
Kunihiro Kaihatsu ${ }^{1 *}$, Chiharu Kawakami ${ }^{2}$ and Nobuo Kato ${ }^{1}$ \\ ${ }^{1}$ The Institute of Scientific and Industrial Research, Osaka University, 8-1 Mihogaoka, Ibaraki, Osaka 567-0047, Japan \\ ${ }^{2}$ Yokohama City Institute of Health, 1-2-17 Takigashira, Isogo-ku, Yokohama 235-0012, Japan
}

\begin{abstract}
Natural phenolic compounds have been reported to directly inhibit influenza virus. Nonetheless, there have been no reports on the direct inhibitory effects of coffee ingredients. Here, we fractionated the hydrophobic and hydrophilic components of coffee. The hydrophobic fraction directly inhibited both a seasonal influenza A/Puerto Rico/8/24(H1N1) virus and a neuraminidase-resistant influenza A/Yokohama/77/2008(H1N1) virus infection in a dosedependent manner, while the hydrophilic fraction did not show any inhibitory effects, even at concentrations above $100 \mu \mathrm{g} / \mathrm{ml}$. The HPLC profile of the hydrophobic fraction indicated that caffeine is the major component. Indeed, caffeine alone showed comparable anti-influenza virus activity. Interestingly, caffeic acid also inhibited viral infection, while chlorogenic acid, which is an ester of caffeic acid and (-)-quinic acid, showed no obvious antiviral effect at less than $2 \mathrm{mg} / \mathrm{ml}$. We previously reported a method for enhancing the anti-influenza virus activity of epigallocatechin gallate, a major tea catechin, by lipase-catalyzed acylation. Using this methodology, we synthesized fatty acid esters of caffeic acid and evaluated their influenza virus-inhibitory effects. It was found that dioctanoyl ester of caffeic acid exhibited approximately 38-fold higher direct antiviral activity. To understand the essential structure required for virus inhibition, we further examined the antiviral activity of natural flavonoids containing either the caffeic acid skeleton or its analogous structure. Flavonols (quercetin, myricetin and morin) and hexahydrobenzophenone containing extended planar pi-conjugated systems efficiently inhibited the virus infection. Flavonoids possessing both radical scavenging activity and cytotoxicity tended to show higher antiviral activity, probably due to their affinity with viral surface factors. On the other hand, there was no apparent correlation between their antiviral activity and antioxidative activity. These findings provide insight into the design of anti-influenza virus agents from natural polyphenols.
\end{abstract}

Keywords: Coffee extracts; Caffeic acid; Caffeine; Influenza virus; Flavonoids; Fatty acid esters; Antiviral activity; Antioxidative activity; Antiradical activity; Cytotoxicity

Abbreviations: PFU: Plaque Formation Unit; $\mathrm{IC}_{50}$ : $50 \%$ Inhibitory Concentration; $\mathrm{CC}_{50}: 50 \%$ Cytotoxic Concentration; DMSO: Dimethylsulfoxide; DPPH: 1,1-diphenyl-2-picrylhydrazyl radical; MDCK: Madin-Darby Canine Kidney; DMEM: Dulbecco's Modified Eagle's Medium; SOD: Superoxide dismutase-like; MTT: 3-[4,4-dimethylthiazol-2-yl]-2,5-diphenyltetrazolium bromide; EtOAc: Ethyl Acetate; Wat: Water; ND: Not Determined

\section{Introduction}

The threat of an influenza virus pandemic is increasing worldwide, highlighting the need for an antiviral agent that is able to inhibit a broad spectrum of viral infection. Current anti-influenza virus agents mainly target neuraminidase, an enzyme that plays an essential role in the release and spread of progeny virions, following the intracellular viral replication cycle. However, more than $90 \%$ of seasonal influenza viruses isolated in the northern hemisphere in 2008/2009 season were oseltamivir phosphate-resistant strains [1]. Although previously approved neuraminidase inhibitors can inhibit oseltamivir phosphateresistant viruses [2,3], we must also be prepared for outbreaks of novel resistant strains.

On the other hand, green tea catechins have been reported to possess anti-influenza virus activity in vitro [4] and in vivo [5]. We reported that epigallocatechin gallate, a major green tea catechin, and its fatty acid derivatives directly inhibit various types of influenza virus including neuraminidase inhibitor resistant viruses [6,7]. Natural flavonoids in pomegranate [8], berries [9], and plant seeds [10] have also been reported to be effective for inhibition of virus infection. However, little is known about the antiviral activity of coffee extracts [10,11], despite its status as the most-consumed drink in the world.

The aim of this study is to obtain potent anti-influenza virus compounds from coffee ingredients and to propose novel anti-influenza virus agents from natural food ingredients.

\section{Materials and Methods}

Coffee beans: Blend coffee (UCC Co. Ltd.; Produced in Colombia, $100 \%$ Arabica bean), Kona coffee (Hawaii Coffee Company; Produced in Hawaii, $100 \%$ Arabica bean). Coffee ingredients: caffeine, hesperetin, and ellagic acid were purchased from Wako Pure Chemical Industries, Ltd. (Osaka, Japan), caffeic acid and taxifolin were purchased from Enzo Life Sciences (Tokyo, Japan), (-)-quinic acid, naringenin, morin hydrate, hexahydroxybenzophenone, gallic acid and ethyl gallate were purchased from Tokyo Kasei Co. Ltd. (Tokyo, Japan). Chlorogenic acid was obtained from Wako. Luteolin, quercetin and myricetin were purchased from Cayman (Ann Arbor, MI), MDCK cells were obtained from Dainippon Sumitomo Seiyaku, DMEM was from Wako, fetal bovine serum was from MP Biomedicals, Inc., (Solon, OH), bovine serum albumin and agar were from Sigma-Aldrich (Tokyo, Japan), trypsin-EDTA was from Nacalai Tesque (Kyoto, Japan). Other chemicals were purchased from Wako Pure Chemical Industries, Ltd. unless otherwise noticed.

General procedures for organic synthesis: Reagents and solvents

*Corresponding author: Kunihiro Kaihatsu, The Institute of Scientific and Industrial Research, Osaka University, 8-1 Mihogaoka, Ibaraki, Osaka 567-0047, Japan, Tel: +81-6-6879-8471; Fax: +81-6-6879-8474; E-mail: Kunihiro@sanken. osaka-u.ac.jp

Received January 16, 2014; Accepted February 20, 2014; Published February 22, 2014

Citation: Kaihatsu K, Kawakami C, Kato N (2014) Potential Anti-Influenza Virus Agents Based on Coffee Ingredients and Natural Flavonols. Nat Prod Chem Res 2 129 doi:10.4172/ 2329-6836.1000129

Copyright: @ 2014 Kaihatsu K, et al. This is an open-access article distributed under the terms of the Creative Commons Attribution License, which permits unrestricted use, distribution, and reproduction in any medium, provided the original author and source are credited. 
were obtained from commercial sources without further purification unless otherwise noted. The reaction process was monitored by Thin layer chromatography on Silicagel 60F254 (MerkKGaA, Darmstadt, Germany) and a UV illuminator at $254 \mathrm{~nm}$ (Funakoshi Corporation, Tokyo, Japan). 1H NMR spectra were recorded on a JEOL ECS 400 spectrometer (JOEL, Tokyo, Japan). Chemical shifts were reported in terms of $\delta(\mathrm{ppm})$ relative to tetramethylsilane in dimethylsulfoxide-d6 (Acros Organics, Tokyo, Japan). All coupling constants are given in $\mathrm{Hz}$. Flash column chromatography was performed on silica gel (40-63 $\mu \mathrm{m})$ under a pressure of about 4 psi. Organic solvents were evaporated using a rotary evaporator N-1000V (Shibata Scientific \& Technology Ltd., Saitama, Japan), a SYS-20WR pomp (Yamato Scientific Co., Ltd. Tokyo, Japan) and a coolant Coolman Pal C-330 (Shibata). Aqueous solutions were lyophilized using a DC 400 Freeze Dryer (Yamato) and a rotary vacuum pump (Hitachi Ltd., Tokyo, Japan). Samples were analyzed by reverse-phase HPLC using a JASCO PU-2080 plus pump system (Tokyo, Japan), a JASCO UV-2075 detector, a AS-2055 plus intelligent autosampler, a MX-2080-32 Mixer, a DG-2080-53 degasser, a GL Science Inertsil WP $300 \mathrm{C}-18$ column $(150 \mathrm{~mm} \times 4.6 \mathrm{~mm})$ and a $5 \mu \mathrm{m} \mathrm{C}-18$ column. Elution was performed with $30 \%$ methanol and $70 \% 5 \mathrm{mM}$ potassium phosphate buffer $(\mathrm{pH} 2.5)$ at a flow rate of 0.4 $\mathrm{ml} / \mathrm{min}$ for $22 \mathrm{~min}$. Chromatographic peaks were detected with a UV detector at a wavelength of $280 \mathrm{~nm}$. Mass spectra were obtained by a LTQ orbitrap XL (Thermo Scientific, Yokohama, Japan) and melting temperatures were obtained by a MP-S3 micro melting point apparatus (Yanaco New Science Inc., Kyoto, Japan).

\section{Extraction of coffee bean ingredients}

Commercially available ground coffee (Blend coffee or Kona coffee; $30 \mathrm{~g}$ ) was subjected to extraction in $250 \mathrm{ml}$ of hot water. Extracts were immediately cooled on an ice bath and hydrophobic compounds were extracted with ethyl acetate. Subsequently, the ethyl acetate phase was dried with magnesium sulphate and filtered, and the ethyl acetate was evaporated using a rotary evaporator. The remaining water phase was frozen in liquid nitrogen and subsequently freeze-dried using a lyophilizer.

\section{HPLC analysis of coffee extracts and coffee ingredients}

Dried powder of ethyl acetate extract and remaining water extract were individually dissolved in $1.0 \%$ methanol aqueous solution and the concentration was adjusted to $0.2 \mathrm{mg} / \mathrm{ml}$. Samples were analyzed by octadecyl-modified silica gel column using eluents composed of $30 \%$ methanol and $70 \% 5 \mathrm{mM}$ potassium phosphate buffer ( $\mathrm{pH}$ 2.5). Chromatographic peaks were detected with a UV detector at a wavelength of $280 \mathrm{~nm}$. Major coffee bean ingredients such as caffeine, caffeic acid and quinic acid shown in Figure 1 were analyzed by this method.

Influenza virus inhibitory assay for coffee extracts, coffee ingredients, octanoyl esters of caffeic acid, natural flavonoid and gallic acid derivatives

In order to evaluate the influenza virus-inhibitory effects of coffee extracts, coffee ingredients, natural flavonoids and their derivatives, we employed plaque formation inhibitory assay [12]. A monolayer of Madin-Darby Canine Kidney (MDCK) was prepared in a 6-well plate. Each sample was dissolved in DMEM containing 1.0\% dimethyl sulfoxide (DMSO) and was directly incubated with influenza A/Puerto Rico/8/34/H1N1 or A/Yokohama/77/2008/H1N1 virus for $30 \mathrm{~min}$ prior to inoculation. Virus solution was then added to a monolayer of MDCK cells, and was incubated for $1 \mathrm{~h}$ at $37^{\circ} \mathrm{C}$. Cell sheets were washed with Phosphate-Buffered Saline (PBS), and were incubated with DMEM containing $0.8 \%$ agar for 2 days at $37^{\circ} \mathrm{C}$. Cell sheets were fixed with $5 \%$ glutaraldehyde and the overlay agarose was removed, after which cell sheets were stained with $0.02 \%$ methylene blue solution. Plaques formed on each well were counted and the inhibitory effects of each sample on virus infection were evaluated. As a positive control, we employed quercetin, which is known to possess influenza virus inhibitory effects [13].

\section{Synthesis of octanoyl esters of caffeic acid by lipase-catalyzed acylation}

Synthesis of octanoyl esters of caffeic acid was accomplished using the previously reported lipase-catalyzed transesterification method [6] Briefly, lipase PL from Alcaligenes sp. (100 mg) was added to $20 \mathrm{ml}$ of $\mathrm{N}$, $\mathrm{N}$-dimethylformamide solution containing $4(200 \mathrm{mg}, 1.12 \mathrm{mmol})$ and vinyl palmitate $(756 \mathrm{mg}, 4.44 \mathrm{mmol})$. The mixture was stirred for $36 \mathrm{~h}$ at $57^{\circ} \mathrm{C}$. After filtration of the reaction mixture, $100 \mathrm{ml}$ of ethyl acetate was added to the solvent, which was washed three times with brine, three times with $5 \% \mathrm{NaHCO}_{3}$ aq and three times with $5 \% \mathrm{HCl}$ aq. The organic phase was dried with $\mathrm{Na}_{2} \mathrm{SO}_{4}$, filtered, and the ethyl acetate was removed using a rotary evaporator vacuum system. The residue was purified by silica gel column chromatography using a mixture of $92 \%$ chloroform and $8 \%$ methanol, which resulted in 33\% of a mixture of monooctanoyl esters $\mathbf{6 a}$ and $\mathbf{6 b}$ (white solid, Rf value; 0.28 (chloroform: methanol=90:10 (v/v)) and 10\% of dioctanoyl ester 7 (white solid, Rf value; 0.56 (chloroform: methanol=90:10 (v/v)).

${ }^{1} \mathrm{H} \quad \mathrm{NMR}$ of $\mathbf{6 a} \quad\left(400 \mathrm{MHz}, \mathrm{CD}_{3} \mathrm{OD}\right) \quad 0.918 \quad(3 \mathrm{H}, \quad \mathrm{t}$, $\left.\mathrm{J}=7.2 \mathrm{~Hz}, \quad-\mathrm{COCH}_{2} \mathrm{CH}_{2} \mathrm{CH}_{2} \quad\left(\mathrm{CH}_{2}\right)_{3} \mathrm{CH}_{3}\right), \quad 1.340 \quad(6 \mathrm{H}, \quad \mathrm{m}$, $\left.-\mathrm{COCH}_{2} \mathrm{CH}_{2} \mathrm{CH}_{2}\left(\mathrm{CH}_{2}\right)_{3} \mathrm{CH}_{3}\right), 1.444\left(2 \mathrm{H}, \mathrm{t}, \mathrm{J}=7.2 \mathrm{~Hz},-\mathrm{COCH}_{2} \mathrm{CH}_{2} \mathrm{CH}_{2}\right.$ $\left.\left(\mathrm{CH}_{2}\right)_{3} \mathrm{CH}_{3}\right), 1.735\left(2 \mathrm{H}, \mathrm{t}, \mathrm{J}=7.2 \mathrm{~Hz},-\mathrm{COCH}_{2} \mathrm{CH}_{2} \mathrm{CH}_{2}\left(\mathrm{CH}_{2}\right)_{3} \mathrm{CH}_{3}\right)$, $2.595\left(2 \mathrm{H}, \mathrm{t}, \mathrm{J}=7.2 \mathrm{~Hz},-\mathrm{COCH}_{2} \mathrm{CH}_{2} \mathrm{CH}_{2}\left(\mathrm{CH}_{2}\right){ }_{3} \mathrm{CH}_{3}\right), 6.379(1 \mathrm{H}, \mathrm{d}$, $\mathrm{J}=16 \mathrm{~Hz},-\mathrm{CHCHCOOH}), 6.988(1 \mathrm{H}, \mathrm{d}, \mathrm{J}=8.4 \mathrm{~Hz}, 2$-phenyl proton), $7.058\left(1 \mathrm{H}, \mathrm{dd}, \mathrm{J}_{1}=1.6 \mathrm{~Hz}, \mathrm{~J}_{2}=8.0 \mathrm{~Hz}, 6\right.$-phenyl proton $), 7.115(1 \mathrm{H}, \mathrm{d}$, $\mathrm{J}_{1}=1.6 \mathrm{~Hz}, 5$-phenyl proton), $7.535(1 \mathrm{H}, \mathrm{d}, \mathrm{J}=16 \mathrm{~Hz},-\mathrm{CHCHCOOH})$. Melting point: $125^{\circ} \mathrm{C}$, ESI-MS calculated for $\mathrm{C}_{17} \mathrm{H}_{22} \mathrm{O}_{5}, 306.35$; found, $\mathrm{m} / \mathrm{z} 329.14[\mathrm{M}+\mathrm{Na}]+$

${ }^{1} \mathrm{H}$ NMR of $\mathbf{6 b}(400 \mathrm{MHz}, \mathrm{CD} 3 \mathrm{OD}): 0.918(3 \mathrm{H}, \mathrm{t}, \mathrm{J}=7.2 \mathrm{~Hz}$, $\left.-\mathrm{COCH}_{2} \mathrm{CH}_{2} \mathrm{CH}_{2} \quad\left(\mathrm{CH}_{2}\right)_{3} \mathrm{CH}_{3}\right), 1.340 \quad\left(6 \mathrm{H}, \quad \mathrm{m}, \quad-\mathrm{COCH}_{2} \mathrm{CH}_{2} \mathrm{CH}_{2}\right.$ $\left.\left(\mathrm{CH}_{2}\right)_{3} \mathrm{CH}_{3}\right), 1.444\left(2 \mathrm{H}, \mathrm{t}, \mathrm{J}=7.2 \mathrm{~Hz},-\mathrm{COCH}_{2} \mathrm{CH}_{2} \mathrm{CH}_{2}\left(\mathrm{CH}_{2}\right)_{3} \mathrm{CH}_{3}\right), 1.735$ $\left(2 \mathrm{H}, \mathrm{t}, \mathrm{J}=7.2 \mathrm{~Hz},-\mathrm{COCH}_{2} \mathrm{CH}_{2} \mathrm{CH}_{2}\left(\mathrm{CH}_{2}\right)_{3} \mathrm{CH}_{3}\right), 2.603(2 \mathrm{H}, \mathrm{t}, \mathrm{J}=7.2 \mathrm{~Hz}$, $\left.-\mathrm{COCH}_{2} \mathrm{CH}_{2} \mathrm{CH}_{2}\left(\mathrm{CH}_{2}\right)_{3} \mathrm{CH}_{3}\right), 6.299(1 \mathrm{H}, \mathrm{d}, \mathrm{J}=16 \mathrm{~Hz},-\mathrm{CHCHCOOH}$ ), $6.913(1 \mathrm{H}, \mathrm{d}, \mathrm{J}=8.4 \mathrm{~Hz}, 2$-phenyl proton), $7.249(1 \mathrm{H}, \mathrm{d}, \mathrm{J}=2.0 \mathrm{~Hz}$,

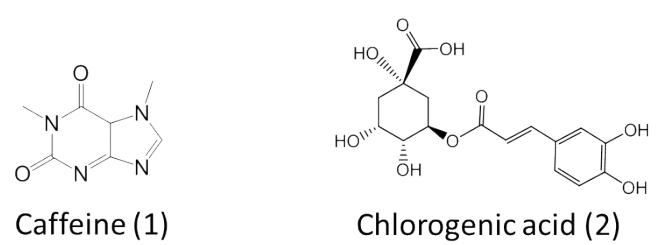<smiles>O=C(O)C1(O)CC(O)[C@H](O)[C@H](O)C1</smiles><smiles>O=C(O)C=Cc1ccc(O)c(O)c1</smiles>

Quinic acid (3) Caffeic acid(4) Shikimic acid (5)

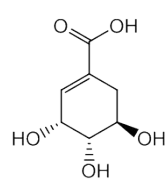

Quinic acid (3) Caffeic acid(4) Shikimic acid (5)

Figure 1: Chemical structures of major coffee ingredients (1-4) and shikimic acid (5). 
a)

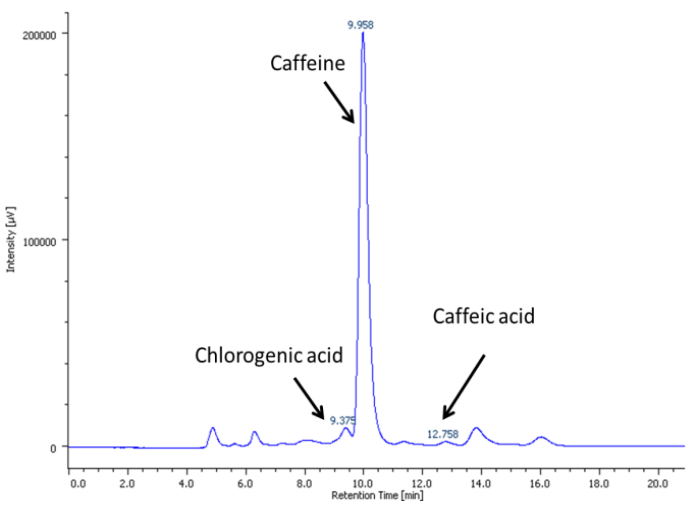

c)

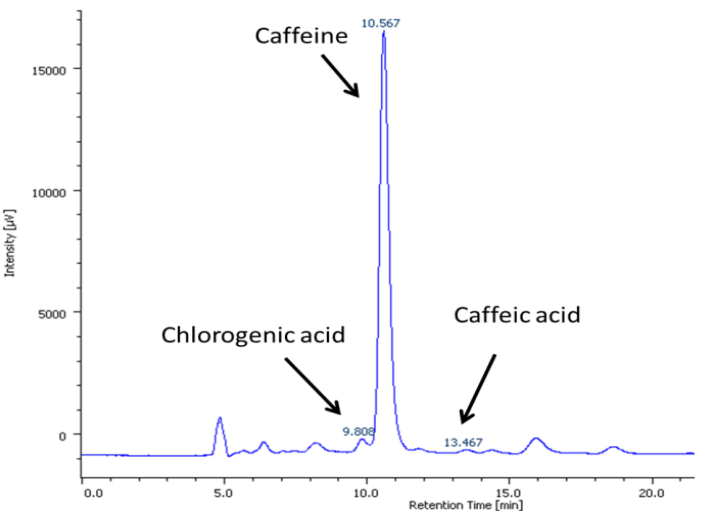

b)

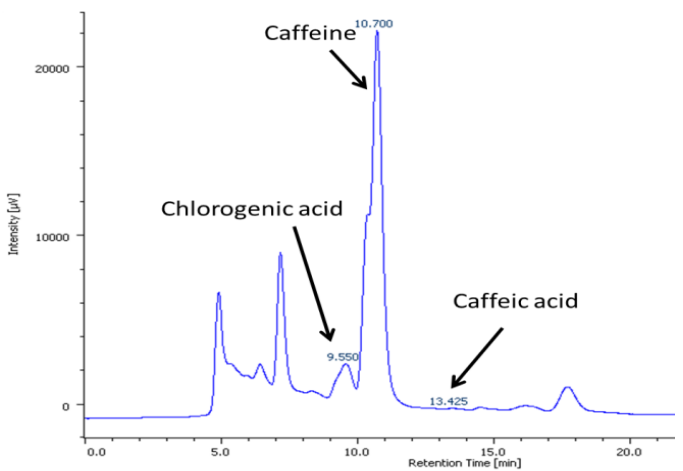

d)

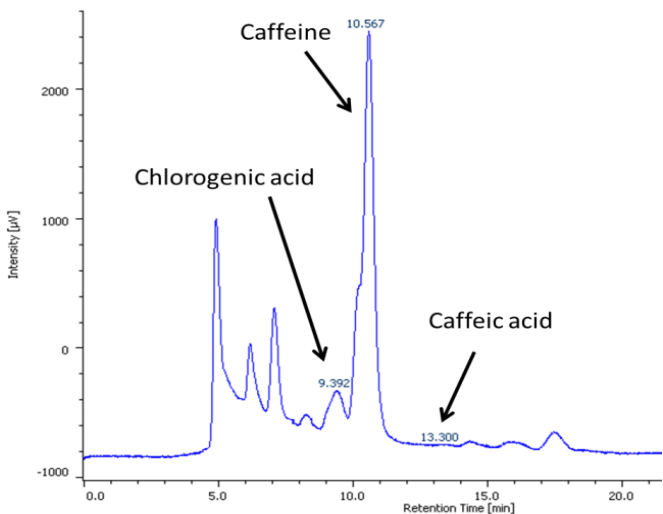

e)

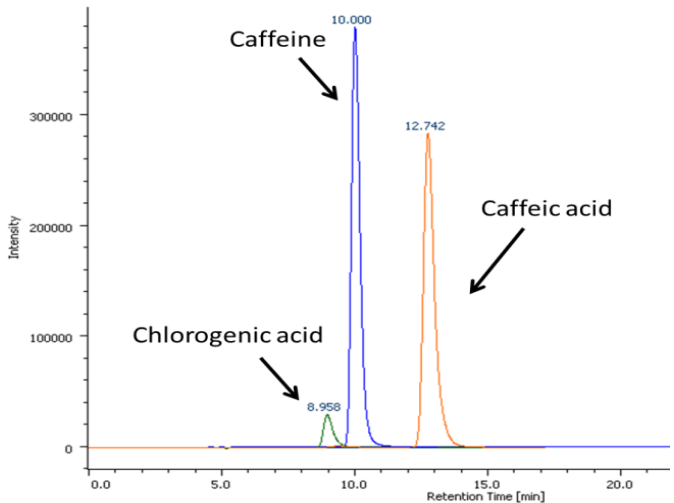

Figure 2: HPLC profiles of coffee bean extracts and the major coffee ingredients. Phenolic compounds in each fraction were detected by UV absorbance at $280 \mathrm{~nm}$ and their HPLC chromatograms are shown in Figures 2a-2d. a) ethyl acetate phase of Blend coffee, b) water phase of Blend coffee, c) ethyl acetate phase of Kona coffee, and d) water phase of Kona coffee. e) Retention time of chlorogenic acid, caffeine, and caffeic acid.

5-phenyl proton), 7.330( $1 \mathrm{H}, \mathrm{dd}, \mathrm{J}_{1}=2.0 \mathrm{~Hz}, \mathrm{~J}_{2}=8.4 \mathrm{~Hz}, 6$-phenyl proton), $7.547(1 \mathrm{H}, \mathrm{d}, \mathrm{J}=16 \mathrm{~Hz},-\mathrm{CHCHCOOH})$. Melting point: $125^{\circ} \mathrm{C}$, ESI-MS calculated for $\mathrm{C}_{17} \mathrm{H}_{22} \mathrm{O}_{5}, 306.35$; found, $\mathrm{m} / \mathrm{z} 329.14[\mathrm{M}+\mathrm{Na}]+$

${ }^{1} \mathrm{H}$ NMR of $7\left(400 \mathrm{MHz}, \mathrm{CD}_{3} \mathrm{OD}\right): 0.914(6 \mathrm{H}, \mathrm{t}, \mathrm{J}=7.2 \mathrm{~Hz}, 2 \mathrm{x}$ $\left.-\mathrm{COCH}_{2} \mathrm{CH}_{2} \mathrm{CH}_{2}\left(\mathrm{CH}_{2}\right)_{3} \mathrm{CH}_{3}\right), 1.331\left(16 \mathrm{H}, \mathrm{m}, 2 \mathrm{x}-\mathrm{COCH}_{2} \mathrm{CH}_{2} \mathrm{CH}_{2}\right.$ $\left.\left(\mathrm{CH}_{2}\right)_{3} \mathrm{CH}_{3}\right), 1.712\left(4 \mathrm{H}, \mathrm{m}, \mathrm{J}=7.2 \mathrm{~Hz}, 2 \mathrm{x}-\mathrm{COCH}_{2} \mathrm{CH}_{2} \mathrm{CH}_{2}\left(\mathrm{CH}_{2}\right)_{3} \mathrm{CH}_{3}\right)$, $2.561\left(2 \mathrm{H}, \mathrm{t}, \mathrm{J}=7.2 \mathrm{~Hz},-\mathrm{COCH}_{2} \mathrm{CH}_{2} \mathrm{CH}_{2}\left(\mathrm{CH}_{2}\right)_{3} \mathrm{CH}_{3}\right), 2.575(2 \mathrm{H}, \mathrm{t}$, $\left.\mathrm{J}=7.2 \mathrm{~Hz},-\mathrm{COCH}_{2} \mathrm{CH}_{2} \mathrm{CH}_{2}\left(\mathrm{CH}_{2}\right)_{3} \mathrm{CH}_{3}\right), 6.473(1 \mathrm{H}, \mathrm{d}, \mathrm{J}=15.2 \mathrm{~Hz}$, - $\mathrm{CHCHCOOH}), 7.236(1 \mathrm{H}, \mathrm{d}, \mathrm{J}=8.0 \mathrm{~Hz}, 2$-phenyl proton), $7.457(1 \mathrm{H}, \mathrm{d}$, $\mathrm{J}=1.6 \mathrm{~Hz}, 5$-phenyl proton), $7.503\left({ }^{1} \mathrm{H}, \mathrm{dd}, \mathrm{J}_{1}=2.0 \mathrm{~Hz}, \mathrm{~J}_{2}=8.8 \mathrm{~Hz}, 6\right.$-phenyl proton) $7.586(1 \mathrm{H}, \mathrm{d}, \mathrm{J}=16 \mathrm{~Hz},-\mathrm{CHCHCOOH})$. Melting point: $98^{\circ} \mathrm{C}$, ESI-MS calculated for $\mathrm{C}_{25} \mathrm{H}_{36} \mathrm{O}_{6}, 432.55$; found, $\mathrm{m} / \mathrm{z}$ 455.24[M +Na]+

SOD-like activities of natural flavonoids and gallic acid derivatives

SOD-like activity of polyphenolic compounds was determined by SOD assay kit-WST (Dojindo Molecular Technologies, Inc., Tokyo, Japan) as specified by the manufacturer. Briefly, test compounds were dissolved in DMSO and were then serially diluted in dilution solution. Each test compound was mixed with xanthein oxidase solution followed 
by addition of xanthine solution. The mixture was incubated for 30 min at $37^{\circ} \mathrm{C}$, and the reduction in WST- 1 formazan was monitored by absorbance at $450 \mathrm{~nm}$.

\section{DPPH (1,1-diphenyl-2-picrylhydrazyl) radical scavenging activity natural flavonoids and gallic acid derivatives}

The radical scavenging activity of each sample on DPPH radicals was assessed using the method described by Gažák et al. [14] with some modification. A stock solution $(1 \mathrm{mM})$ of each sample was prepared and diluted with methanol to various concentrations $(0,1.56,3.13,6.25$, $12.5,25.0,50.0$ and $100 \mu \mathrm{M})$. An aliquot of $50 \mu \mathrm{L}$ of each dilution was transferred to a 96-well microplate (Corning, Tokyo, Japan). A working solution of DPPH $(100 \mu \mathrm{M})$ in methanol was prepared and then an aliquot of $150 \mu \mathrm{l}$ was added to each well. After incubation for $30 \mathrm{~min}$ at ambient temperature, quenching at an absorbance of $490 \mathrm{~nm}$ was measured on a microplate reader (Biorad, Tokyo, Japan). Each dilution was performed in triplicate. Free radical-scavenging activities of test samples are expressed in terms of $\mathrm{IC}_{50}$ values, which is the concentration of a sample required to decrease the absorbance at $490 \mathrm{~nm}$ by $50 \%$ when compared to the control response.

\section{Cell culture}

MDCK cells were grown in DMEM supplemented with $10 \%$ foetal bovine serum and maintained in a humidified incubator at $37^{\circ} \mathrm{C}$ with $5 \% \mathrm{CO}_{2}$ upon reaching confluence. Cells were trypsinized and passaged.

\section{Cytotoxicity of coffee ingredients, natural flavonoids and} their derivatives

The cytotoxicity of coffee extracts, coffee ingredients, natural flavonoids and their derivatives were examined by cell growth proliferation (MTT) assay. MDCK cells were seeded onto a 96-well plate and each sample was added to cells in a serial dilution from 2 $\mathrm{mM}$. At $1 \mathrm{~h}$ post-incubation, cells were washed twice with PBS and subsequently incubated with DMEM for $24 \mathrm{~h}$ at $37^{\circ} \mathrm{C}$. Cells were then washed twice with PBS and cell proliferation activity was monitored by MTT assay in accordance with the manufacturer's protocol.

\section{Results and Discussion}

\section{HPLC analysis of coffee bean extracts}

Coffee ingredients in the ethyl acetate phase of blend coffee (BlendEtOAc) and Kona coffee (Kona-EtOAc) were monitored by absorbance at UV $280 \mathrm{~nm}$ and are shown in Figure 2a and 2c. Coffee ingredients in the water phase of Blend coffee (Blend-Wat) and Kona coffee (KonaWat) were also monitored under the same conditions and are shown in Figure $2 \mathrm{~b}$ and $2 \mathrm{~d}$. From their peak profiles on HPLC chromatograms, phenolic compounds in each coffee extract were almost the same, regardless of the production region. The total peak intensity in the ethyl acetate phase was 5 to 8 -fold higher than that of the water phase. To identify some of peaks in the chromatograms, we analyzed caffeine (1), chlorogenic acid (2) and caffeic acid (4) under the same analytical conditions, and found that their peaks appeared around 9, 10, and 13 min, respectively (Figure 2e). According to the HPLC profile in Figure $2 \mathrm{a}-2 \mathrm{~d}$, chlorogenic acid, caffeine and caffeic acid appeared at 9.3759.808 $\mathrm{min}$, 9.958-10.700 $\mathrm{min}$ and $12.759-13.467 \mathrm{~min}$, respectively. Caffeine seemed to be the major aromatic ingredient in coffee extract, although the molar extinction coefficient of each compound differed at $280 \mathrm{~nm}$.

\section{Influenza virus inhibition activity of coffee extracts}

The ethyl acetate phase of blend coffee (Blend-EtOAc) and Kona coffee (Kona-EtOAc) inhibited influenza A/Puerto Rico/8/34/ H1N1(PR8) in a dose-dependent manner, regardless of the production region (Figure 3 ). The $50 \%$ virus inhibitory concentration $\left(\mathrm{IC}_{50}\right.$ ) values for Blend-EtOAc and Kona-EtOAc were $17.5 \mu \mathrm{g} / \mathrm{ml}$ and $7.2 \mu \mathrm{g} / \mathrm{ml}$. On the other hand, the water phase of blend coffee (Blend-Wat) did not show virus-inhibitory effects, even at $100 \mu \mathrm{g} / \mathrm{ml}$ (Figure 3). These results indicate that the antiviral components are mainly present in the ethyl acetate extracted phase. Blend-EtOAc also inhibited infection by oseltamivir-resistant influenza A/Yokohama/77/2008/H1N1 and the $\mathrm{IC}_{50}$ was $3.9 \mu \mathrm{g} / \mathrm{ml}$ (Figure 3). The antiviral effects of coffee extracts varied depending on target viral strain. Although further study is required in order to understand the mode of action, these data indicate that coffee ingredients bind differently to each viral surface component.

\section{Influenza virus inhibitory assay of caffeine and caffeic acid}

In order to understand the antiviral components in coffee extract, we examined the virus-inhibitory effects of 1, 2 and 4. Both 1 and 4 inhibited influenza A/Puerto Rico/8/34/H1N1 (PR8) in a dosedependent manner and the $\mathrm{IC}_{50}$ values were $19.1 \mu \mathrm{g} / \mathrm{ml}(98.0 \mu \mathrm{M})$ and $53.9 \mu \mathrm{g} / \mathrm{ml}(299 \mu \mathrm{M})$ (Figure 4). It has been reported that $\mathbf{1}$ is able to inhibit the expression of hemagglutinin protein in influenza A/Aichiinfected MDCK cells [10]. However, there have been no reports on whether $\mathbf{1}$ and $\mathbf{4}$ are able to directly inactivate influenza virus infectivity. In contrast to our expectations, $\mathbf{2}$ did not show virus-inhibitory effects even at concentrations of $100 \mu \mathrm{g} / \mathrm{ml}(282 \mu \mathrm{M})$. This indicates that the caffeic acid moiety of $\mathbf{2}$ is important for the virus inhibitory effects and the quinic acid moiety in $\mathbf{2}$ hinders the interaction between its caffeic acid moiety and viral surface components.

\section{Influenza virus inhibitory assay of fatty acid esters of caffeic} acid

We prepared monooctanoyl ester $(\mathbf{6 a}+\mathbf{6 b})$ and dioctanoyl ester (7) of caffeic acid by lipase-catalyzed acylation (Figure 5). They showed enhanced anti-influenza virus activity against A/Puerto Rico/8/34/

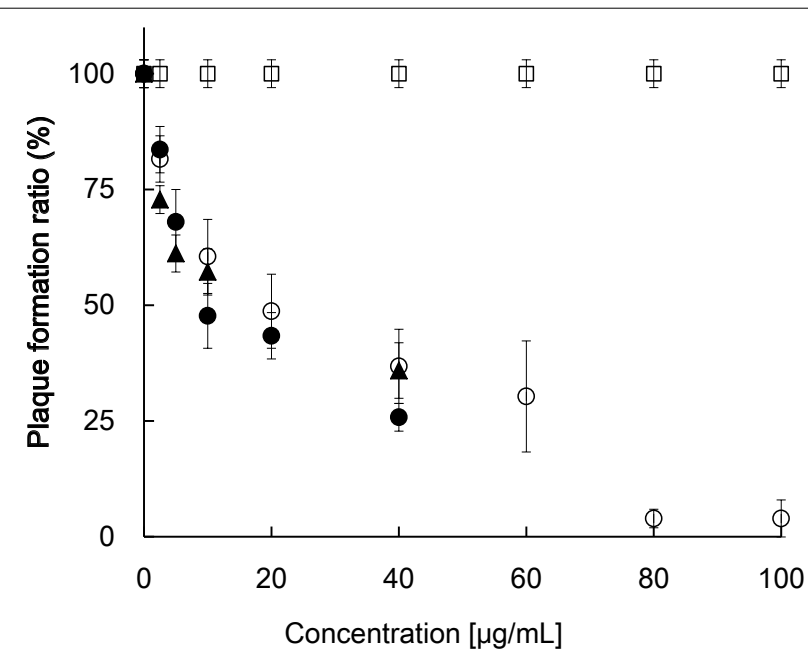

Figure 3: Influenza virus inhibitory effects of ethyl acetate extracts and remaining water extracts of coffee. Open circles: antiviral effects of ethyl acetate extract of blend coffee on influenza A/PR8; Closed triangles: antiviral effects of ethyl acetate extract of blend coffee on influenza A/Yokohama; Closed circles: antiviral effects of ethyl acetate extract of Kona coffee on influenza A/PR8; Open squares: antiviral effects of water phase after ethyl acetate extract on influenza A/PR8. 
$\mathrm{H} 1 \mathrm{~N} 1$. The $\mathrm{IC}_{50}$ values of the monooctanoyl esters $(\mathbf{6} \mathbf{a}+\mathbf{6 b})$ and dioctanoyl ester (7) were $20.9 \mu \mathrm{g} / \mathrm{ml}(68.3 \mu \mathrm{M}, 4.38$-fold) and $3.4 \mu \mathrm{g} / \mathrm{ml}$ $(7.86 \mu \mathrm{M}, 38.0$-fold). It is interesting to note that 7 completely inhibited viral infection at $40 \mu \mathrm{g} / \mathrm{ml}$ (Figure 6). This was probably because the two neighbouring octanoyl groups in 7 increased lipophilicity with the viral membrane, and enhanced the direction of virus-inhibitory effects.

Influenza virus inhibitory assay of natural flavonoids and gallic acid derivatives

Among the flavonoids in Figure 7, quercetin (11), myricetin (12), morin (13) and hexahydroxybenzophenone (16) showed influenza virus-inhibitory effects (Table 1). Other flavonoids that did not show any inhibitory effects at $2,000 \mathrm{ng} / \mathrm{ml}$ were eliminated from further study. Although epigallocatechin (15) has a similar structure to 13, the lack of a planar pai-conjugated system caused the loss of antiviral effects (Table 1). From a structural viewpoint, the above compounds (11, 12, 13 and 16) possess an extended pai-conjugated system and more than two hydroxyl groups in the phenyl group at the C-2 position. Although luteolin (8) meets these criteria, the absence of a hydroxyl group at the C-3 position lowered its antiviral activity.

\section{SOD-like activity of natural flavonoids and gallic acid derivatives}

In order to understand the effects of antioxidative activity on antiviral activity, we evaluated the SOD-like activity of natural flavonoids that contain caffeic acid skeleton or analogous structures (Figure 7). It was found that 8, taxifoline (14), 15 and gallic acid (17) showed SODlike activity (Figure 7 and Table 1). Nevertheless, they did not show apparent antiviral activity at 2,000 $\mathrm{nM}$. This indicates that there is no clear correlation between antioxidative and antiviral activities.

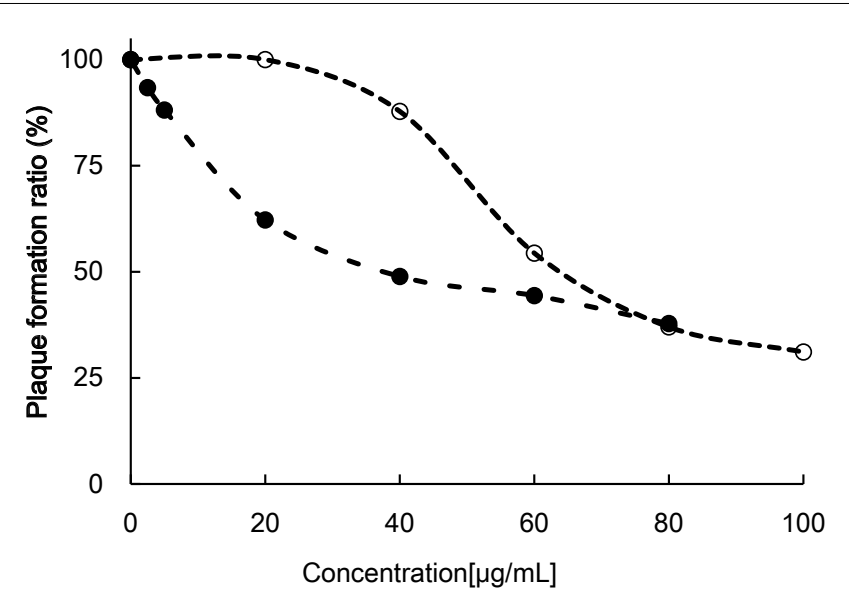

Figure 4: Influenza virus inhibitory effects of caffeine and caffeic acid. Closed circles: caffeine (1); Open circles: caffeic acid (4).

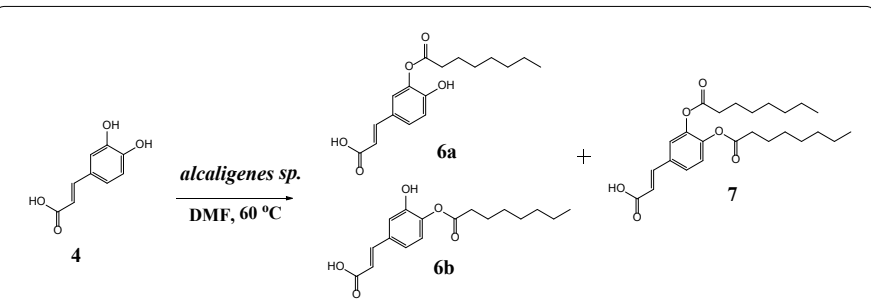

Figure 5: Preparation of octanoyl esters of caffeic acid by a lipase-catalyzed acylation. 6a) 3-O-monooctanoyl ester, 6b) 4-O-monooctanoyl ester, and 7) 3, 4-O-di-octanoyl ester.

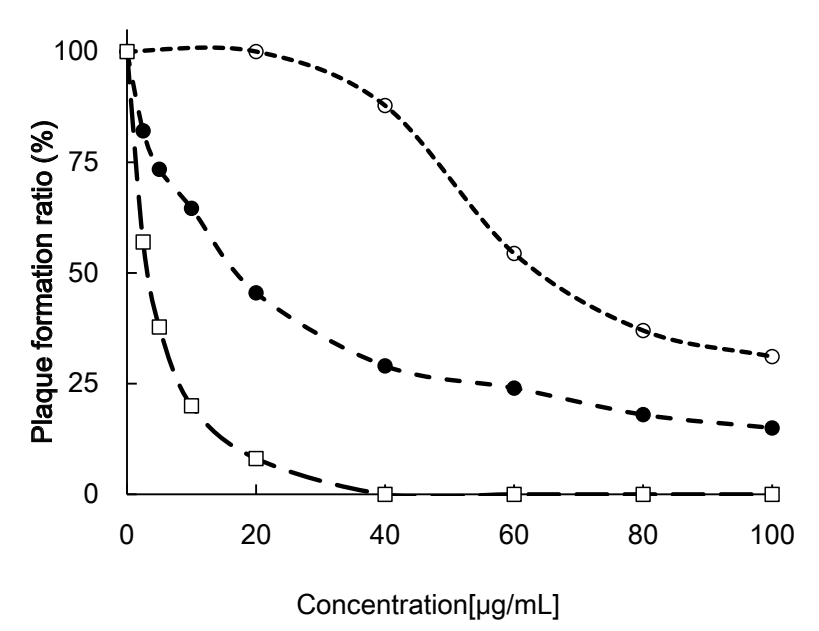

Figure 6: Influenza virus inhibitory effects of caffeic acid and octanoyl esters Open circles: caffeic acid (4), Closed circles: monooctanoyl esters $(6 a+6 b)$, Open squares: dioctanoyl ester (7).

\section{DPPH free radical scavenging activities of natural flavonoids and gallic acid derivatives}

Influenza is an envelope virus. The outer layer is composed of a lipid membrane taken from the host cell. Lipid peroxidation of viral membranes by free radicals may cause serious damage to virus infectivity. Hence, we evaluated DPPH free radical scavenging activity of 8-19 to understand the possible relationship between radical scavenging activity and antiviral activity. Flavone (8), flavonols (11-13) and gallic acid derivatives (16-19) showed radical scavenging activities, and although there may be some correlation, the radical scavenging activities were not sufficient to explain the antiviral activity.

\section{Cytotoxicities of natural flavonoids and gallic acid derivatives}

The cytotoxicity of each compound (8-19) was evaluated by cell proliferation assay. Flavones (8-9), flavonols (11-13) and 16 exhibited relatively high cytotoxic effects when compared with other flavonoids, although their selectivity index $\left(\mathrm{CC}_{50} / \mathrm{IC}_{50}\right)$ was larger than 500 . Interestingly, they all have planar pai-conjugated systems. This may have increased cell membrane permeability. As influenza virus membrane is composed of the host cell membrane, cell membrane affinity and radical scavenging activity may be important for inactivating virus infectivity.

\section{Conclusion}

In conclusion, the coffee ingredients in ethyl acetate extract directly inhibited influenza virus infection. The antiviral compounds in the extract were identified as caffeine and caffeic acid. We introduced octanoyl groups in 3-phenyl group of caffeic acid by a lipase-catalyzed acylation. The dioctanoyl ester showed 38-fold increased anti-influenza virus activity, probably due to its increased lipophilicity to the virus membrane. This simple method can be useful for improving antiinfluenza virus activity of various types of natural phenolic compounds. Meanwhile, we evaluated natural flavonoids that contain a caffeic acid skeleton or analogous structure. From a structural viewpoint, flavonols (11-13) that have both extended pi-conjugated systems and more than two hydroxyl groups in the phenyl group exerted higher antiviral activities (Table 1). Among these three compounds, 13 showed the highest antiviral activity. The neighboring three hydroxyl groups at the B-ring increased the antiradical activity and cell membrane permeability, resulting in higher antiviral activity. Flavanone 10, 


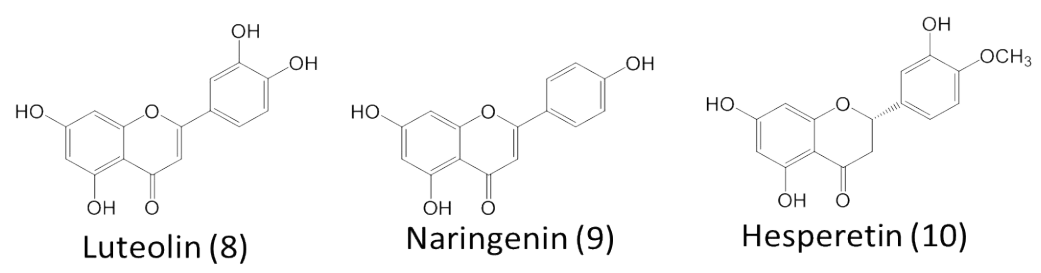<smiles>O=c1c(O)c(-c2ccc(O)c(O)c2)oc2cc(O)cc(O)c12</smiles>

Quercetin (11)

Morin hydrate (12)

Myricetin (13)<smiles>O=C1c2c(O)cc(O)cc2O[C@H](c2ccc(Cl)c(O)c2)C1O</smiles>

Taxifolin (14)<smiles>O=C(O)c1cc(O)c(O)c(O)c1</smiles>

Gallic acid (17)<smiles>Oc1cc(O)c2c(c1)OC(c1cc(O)c(O)c(O)c1)C(O)C2</smiles>

$\mathrm{EGC}(15)$<smiles>O=C(c1cc(O)c(O)c(O)c1)c1ccc(O)c(O)c1O</smiles>

Hexahydrobenzophenone (16)<smiles>O=c1oc2c(O)c(O)cc3c(=O)oc4c(O)c(O)cc1c4c23</smiles>

Ellagic acid (19)

Figure 7: Chemical structures of natural flavonoids (8-15) and gallic acid derivatives (16-19)

\begin{tabular}{|c|c|c|c|c|c|}
\hline & Compound & $\begin{array}{l}\text { Antioxida- } \\
\text { tive activity }{ }^{1} \\
\text { IC }_{50}[\mathrm{nM}]\end{array}$ & $\begin{array}{c}\text { Antiradical } \\
\text { activity }^{2} \\
I_{50}[\mathrm{nM}]\end{array}$ & $\begin{array}{c}\text { Anti-influenza } \\
\text { viral activity } \\
\mathrm{IC}_{50}[\mathrm{nM}]\end{array}$ & $\begin{array}{c}\text { Cytotoxicity } \\
\text { CC504 } \\
{[\mu \mathrm{M}]}\end{array}$ \\
\hline 8 & Luteolin & 51.0 & 73.1 & $>2,000$ & 225 \\
\hline 9 & Naringenin & $>100$ & $>100$ & $>2,000$ & 425 \\
\hline 10 & Hesperetin & ND & $>100$ & $>2,000$ & $>1,000$ \\
\hline 11 & Quercetin & $>100$ & 65.5 & 1,400 & 480 \\
\hline 12 & Morin Hydrate & ND & 71.3 & 1,400 & 425 \\
\hline 13 & Myricetin & 97.1 & 38.9 & 900 & 505 \\
\hline 14 & Taxifolin & 60.9 & $>100$ & $>2,000$ & $>1,000$ \\
\hline 15 & Epigallocatechin & 26.0 & $>100$ & $>2,000$ & $>1,000$ \\
\hline 16 & $\begin{array}{l}\text { Hexahydroxy } \\
\text { benzophenone }\end{array}$ & ND & 25.8 & 900 & 475 \\
\hline 17 & Gallic acid & 22.3 & 51.5 & $>2,000$ & $>1,000$ \\
\hline 18 & Ethyl gallate & ND & 28.4 & $>2,000$ & $>1,000$ \\
\hline 19 & Ellagic acid & ND & 22.6 & $>2,000$ & $>1,000$ \\
\hline
\end{tabular}

${ }^{1}$ Antioxdative activity was measured by superoxide dismutase-like assay

${ }^{2}$ Antiradical activity was measured by DPPH free radical scavenging assay

${ }^{3}$ Anti-influenza virus activity was measured by plaque formation inhibitory assay

${ }^{4}$ Cytotoxity was measured by cell proliferation (MTT) assay

$\mathrm{IC}_{50}$ :the $50 \%$ inhibitory concentration

CC :the $50 \%$ cytotoxic concentration

ND: Not Determined

Table 1: Antioxidative, antiradical and anti-influenza virus activities, and cytotoxicity of natural flavonoids and their analogues.

flavanonol 14, and flavan-3-ol 15, which possess a non-planar structure did not show any virus inhibitory effects at 2,000 nM. This indicates that the double bond between $\mathrm{C} 2$ and $\mathrm{C} 3$ and the carbonyl at $\mathrm{C} 4$ on the center ring are important for retaining antiviral activity. Although flavones 8 and $\mathbf{9}$ have planar structures, the lack of a C3 hydroxyl group lowered the antiviral activity, probably due to reduced water solubility. Gallic acid derivatives 16-19 showed relatively high anti-radical activities, but only $\mathbf{1 6}$ exhibited the antiviral activity. It is possible that 17-19 had insufficient cell membrane permeability. From these data, flavonoids and gallic acid derivatives that contain planar structure and possess both anti-radical activity and cell membrane permeable properties possess anti-influenza virus activity. There were no clear correlations between antioxidative activities and antiviral activities.

Based on the present study, we propose that novel octanoyl esters of caffeic acid and natural flavonoids, such as quercetin (in onion), myricetin (in walnut) and morin (in guava leave) be studied as potential influenza virus-inhibitory agents.

\section{Acknowledgement}

We would like to thank The All Japan Coffee Association (AJCA) for providing research funding. We are grateful to Ms. Junko Hikida, Ms. Hiroyo Masumura and Ms. Azusa Ohta for their supports.

\section{References}

1. (2009) Influenza $\mathrm{A}(\mathrm{H} 1 \mathrm{~N} 1)$ virus resistance to oseltamivir-2008/2009 influenza season, northern hemisphere. World Health Organization, Geneva, Switzerland

2. Yamashita M, Tomozawa T, Kakuta M, Tokumitsu A, Nasu H, et al. (2009) CS 8958, a prodrug of the new neuraminidase inhibitor R-125489, shows longacting anti-influenza virus activity. Antimicrob Agents Chemother 53: 186-192.

3. Smee D, Huffman JH, Morrison AC, Barnard DL, Sidwell RW (2001) Cyclopentane neuraminidase inhibitors with potent in vitro anti-influenza virus activities. Antimicrob Agents Chemother 45: 743-748.

4. Nakayama M, Suzuki K, Toda M, Okubo S, Hara Y, et al. (1993) Inhibition of the infectivity of influenza virus by tea polyphenols. Antiviral Res 21: 289-299. 
5. Nakayama M, Toda M, Okubo S, Hara Y, Shimamura T (1994) [Inhibition of the infectivity of influenza virus by black tea extract]. Kansenshogaku Zasshi 68: 824-829.

6. Mori S, Miyake S, Kobe T, Nakaya T, Fuller SD, et al. (2008) Enhanced antiinfluenza A virus activity of (-)-epigallocatechin-3-O-gallate fatty acid monoester derivatives: effect of alkyl chain length. Bioorg Med Chem Lett 18: 4249-4252.

7. Kaihatsu K, Mori S, Matsumura H, Daidoji T, Kawakami C, et al. (2009) Broad and potent anti-influenza virus spectrum of epigallocatechin-3-O-gallatemonopalmitate. J Mol Genet Med 3: 195-197.

8. Sundararajan A, Ganapathy R, Huan L, Dunlap JR, Webby RJ, et al. (2010) Influenza virus variation in susceptibility to inactivation by pomegranate polyphenols is determined by envelope glycoproteins. Antiviral Res 88: 1-9.

9. Sekizawa H, Ikuta K, Mizuta K, Takechi S, Suzutani T (2013) Relationship between polyphenol content and anti-influenza viral effects of berries. J Sci Food Agric 93: 2239-2241.
10. Sokmen M, Angelova M, Krumova E, Pashova S, Ivancheva S, et al. (2005) In vitro antioxidant activity of polyphenol extracts with antiviral properties from Geranium sanguineum L. Life Sci 76: 2981-2993.

11. Pollikoff R, Liberman M, Cochran KW, Pascale AM (1965) Effect of caffeic acid on mouse and ferret lung infected with influenza $A$ virus. Antimicrob Agents Chemother (Bethesda) 5: 561-566.

12. Gaush CR, Smith TF (1968) Replication and plaque assay of influenza virus in an established line of canine kidney cells. Appl Microbiol 16: 588-594.

13. Davis J, Murphy EA, McClellan JL, Carmichael MD, Gangemi JD (2008) Quercetin reduces susceptibility to influenza infection following stressful exercise. Am J Physiol Regul Integr Comp Physiol 295: R505-509.

14. Gazák R, Purchartová K, Marhol P, Zivná L, Sedmera P, et al. (2010) Antioxidant and antiviral activities of silybin fatty acid conjugates. Eur $\mathrm{J}$ Med Chem 45 1059-1067. 